\title{
Diminutive Polyposis Coli: Should All Polyps be Removed during a Colonoscopy?
}

\author{
Diminütif Polipozis Koli: Kolonoskopi Sırasında Bütün Polipleri Çıkartmalı mıyız?
}

(D) Kamer Tomaoğlu1, (D) Hasan Ökmen²

${ }^{1}$ Esenyurt University School of Medical Sciences, İstanbul, Turkey

2University of Health Sciences Turkey, İstanbul Training and Research Hospital, Clinic of General Surgery, İstanbul, Turkey

\begin{abstract}
Introduction: Colorectal cancer (CRC) is the second most common cause of cancer-related death. Most CRCs arise from colorectal polyps or adenomas. Colonoscopy with polypectomy offers a real-time management of benign adenomas, which breaks the adenoma-carcinoma sequence. In this study, the following question is discussed: should each polyp be excised in patients with more than three diminutive polyps?
\end{abstract}

Methods: The study was conducted in Yedikule Surp Pırgiç Ermeni Hospital between January 2012 and October 2020. The medical records of 2,222 patients who underwent colonoscopy were retrospectively examined. The patients were divided into two groups. The first group included patients with three or fewer polyps, whereas the second group included patients with four or more polyps. In the first group, all polyps were excised regardless of the polyp's diameter. In the second group, all polyps larger than $5 \mathrm{~mm}$ in diameter were excised. A maximum of three polyps were excised in patients who had more than three diminutive polyps. Student's t-test, chi-square test, and Fisher's exact test were used for the statistical analysis. All statistical analyses were performed using SPSS version 18.0 (SPSS Inc., USA). P $<0.05$ was considered statistically significant. Results: The total number of performed colonoscopies was 2,222. Colorectal polyps were detected in 501 (22.5\%) patients. The number of total polypectomies was 728 . Five hundred eighty-nine (81.0\%) polyps had a diameter of $1 \mathrm{~cm}$ or less. Diminutive polyps were detected in 352 (48.4\%) patients. The most common histopathological diagnosis in patients with diminutive polyps was tubular adenoma with mild dysplasia (60.8\%) and inflammatory polyp (31.0\%).

Conclusion: It is concluded that excising all polyps encountered during colonoscopy is appropriate, whether they are diminutive or not. Further studies with a larger case series are needed in this area.

Keywords: Colorectal, diminutive polyp, adenomatous polyp, polypectomy
öZ

Amaç: Kolorektal kanserler, kanserden ölüm nedenleri arasında ikinci sırada yer almaktadır. Bu hastalığın poliplerden geliștiği göz önüne alındığında, düzenli yapılan kolonoskopi ve polipektomi, adenom-karsinom sekansını kırarak hastalığın önlenebilir olduğunu ortaya koymaktadır. Bu çalıșmada "üçten fazla diminutif polipe sahip hastada her polipe eksizyon uygulanmalı mıdır?" sorusu literatür verileri ve istatistiksel sonuçlarımız doğrultusunda tartışılmıștır.

Yöntemler: Çalısma Yedikule Surp Pırgiç Ermeni Hastanesi'nde Ocak 2012 ve Ekim 2020 yılları arasında kolonoskopi yapılmış olan 2.222 hastanın dosyalarının retrospektif olarak gözden geçirilmesi ile yapıldı. Hastalar, üç ve daha az polipi olanlar ile dört ve daha fazla polipi olan hastalar olmak üzere iki guruba ayrılarak incelendi. Birinci grup hastalarda, polip çapına bakmaksızın tüm polipler eksize edildi. İkinci grup hastalarda ise çapları 5 mm'den büyük olan tüm polipler eksize edildi. Eğer sadece diminutif polipozis saptanmışsa 3 adet polipe polipektomi yapıldı, diğer diminutif polipler yerinde bırakıldı. İstatistiksel analizlerde Student's t-test, ki-kare test, Fisher's exact test kullanıldı. Bütün istatistiksel analizler SPSS version 18.0 (SPSS Inc., USA) software programı kullanılarak gerçekleștirildi. İstatistiksel anlamlılık $\mathrm{p}<0,05$ olarak kabul edildi.

Bulgular: Toplam kolonoskopi sayısı 2.222 olgudur ve 501 $(\% 22,5)$ olguda kolorektal polip saptandı. Toplam polipektomi sayısı 728 olarak gerçeklești. Polip çapı $589(\% 81,0)$ polipte 1 cm ve daha küçüktü. Toplam $352(\% 48,4)$ olguda diminutif polip saptandı. Diminutif polipli olgularda en sık karşılaşılan patolojik tanı tübüler adenom-hafif displazi $(\% 60,8)$ ve enflamatuvar polip $(\% 31,0)$ idi.

Sonuç: Diminutif olsun veya olmasın, kolonoskopide karşılaşılan tüm poliplere eksizyon uygulanmasının uygun olacağı kanaatindeyiz. Bu alanda daha geniş olgu serilerine sahip çalışmalara ihtiyaç olduğunu düşünüyoruz.

Anahtar Kelimeler: Kolorektal, diminutif polip, adenomatöz polip, polipektomi 


\section{Introduction}

Colorectal cancers (CRCS) are among the top causes of death from cancer in many western countries, ranking second in the USA (1). Since CRC develop from polyps, due to its diagnostic and therapeutic properties, colonoscopy has a crucial role in following up patients with colon polyps. It is evident that when colonoscopy is performed at regular intervals with classical guideline recommendations, it prevents CRC, which arise from preexisting adenomatous polyps, which represent one-half to twothirds of all colorectal polyps $(2,3)$. Total colonoscopy, with polypectomy of neoplastic polyps, has been associated with a reduced incidence of CRC and decreased mortality $(4,5)$.

More than $90 \%$ of colorectal polyps had a diameter less than $1 \mathrm{~cm}(2,3)$. Polyps with a diameter of $5 \mathrm{~mm}$ or less are called diminutive polyps $(1,4)$. Only $1.7 \%$ of the diminutive polyps are histologically advanced (high-grade dysplasia, villous, tubulovillous, and serrated adenoma) and have the risk of developing CRC $(2,5)$. This statistical result may give an impression that removing all diminutive polyps at first glance is unnecessary. Besides, the excision of many diminutive polyps prolongs the colonoscopy procedure, and it is known that complications can result from invasive procedures.

In this study, considering our statistical results and literature data, the following question is discussed: should each polyp be excised in patients with more than three diminutive polyps?

\section{Methods}

This is a retrospective study, and all the procedures performed were part of routine care. Ethical approval was obtained from istanbul Esenyurt University (approval number: E-12483425-199-748). Written and oral consent were obtained from the patients included in the study, and their data were evaluated within the scope of the study. This study retrospectively reviewed the medical files of patients who underwent colonoscopy in Yedikule Surp Pırgiç Ermeni Hospital between January 2012 and October 2020.

The age, gender, indications of colonoscopy, number and diameter of polyps detected on colonoscopy, number of polypectomies, and complications were recorded. The histopathological result of each polypectomy was evaluated. Both diameters of the polyp specified in the pathological report and the colonoscopic diagnosis were compared, and in case of any discordance, the polyp diameter specified in the pathological diagnosis was considered. All histopathological results of polyps were recorded.

Patients were divided into two groups. The first group included patients with three or fewer polyps, whereas the second group included patients with four or more polyps. In the first group, all polyps were excised regardless of the diameter. In the second group, a maximum of three polyps were excised in patients where only diminutive polyps were detected; the location of diminutive polyps, which were not excised, was described in detail in the colonoscopy report. These patients underwent regular colonoscopic follow-up examinations. Alternatively, in the second group, polyps found on colonoscopy with a diameter greater than $5 \mathrm{~mm}$ were excised.

\section{Statistical analysis}

Student's t-test, chi-square test, and Fisher's exact test were used for statistical analysis. The patients were divided into four groups for age-stratified analysis. All statistical analyses were performed using SPSS version 18.0 (SPSS Inc., USA). P $<0.05$ was considered statistically significant.

\section{Results}

Total colonoscopies performed within the specified period were 2,222, and colorectal polyps were found in 501 patients (22.5\%).

One thousand one hundred twenty-six (50.7\%) patients were men and 1096 were women (49.3\%). A total of 317 (28.2\%) and 184 (16.8\%) polyps were detected in men and women, respectively. The polyp detection rate was significantly higher in men $(p<0.001)$. No complications were encountered in any patient during colonoscopy.

The major clinical indications of colonoscopy were abdominal pain, obstipation or meteorism (40.5\%), and hematochezia (29.8\%). $11.1 \%$ of the patients underwent colonoscopy for routine control or screening. There was a significant difference between men and women $(p<0.001)$ in terms of the indications of colonoscopy. The most common indication of colonoscopy in men was hematochezia (35.2\%), whereas, in women, it was iron-deficiency anemia (42.8\%).

The age-stratified analysis revealed that polyps were most frequent in men over 60 years of age and women over 75 years of age $(p<0.001)$ (Table 1).

The total number of polypectomies performed in 501 patients was 728. When the numbers and diameters of polyps were compared, no statistical significance was found in terms of the distribution $(p=0.610)$ (Table 2).

Diminutive polyps were detected in 352 patients. The rate of diminutive polyp detection was significantly higher in women $(p=0.003)$ (Table 3).

The most common histopathological diagnosis of diminutive polyps was tubular adenoma with mild dysplasia (60.8\%) and inflammatory polyp (31.0\%). Fifteen polyps were reported as serrated adenoma with mild dysplasia (4.3\%), whereas only one patient was diagnosed with tubulovillous adenoma with mild dysplasia (0.3\%). The histopathological results of all patients (with and without diminutive polyps) are given in Table 4.

\section{Discussion}

Colonoscopy is a crucial diagnostic tool for detecting colon polyps, which plays an important role in preventing the development of CRC resulting from polypectomy. There is a consensus on the necessity to excise polyps with a diameter of $1 \mathrm{~cm}$ or more, especially when they have a high malignant potential (6). However, the management of polyps with a diameter of $5 \mathrm{~mm}$ or less, called diminutive polyps, is still controversial.

Recent technological developments in endoscopic imaging techniques have allowed the diagnosis of very small lesions and at the same time help distinguish between low-risk and high-risk lesions by performing simultaneous histopathological evaluations during colonoscopy. These 
technologies are high definition white light, narrow band resolution colonoscopy (NBI), and other narrow band resolution technologies $(7,8)$.
The potential effectiveness of these technologies is that they shorten the duration of colonoscopy, eliminate unnecessary histopathological

\section{Table 1. Distribution of polyps by gender and age}

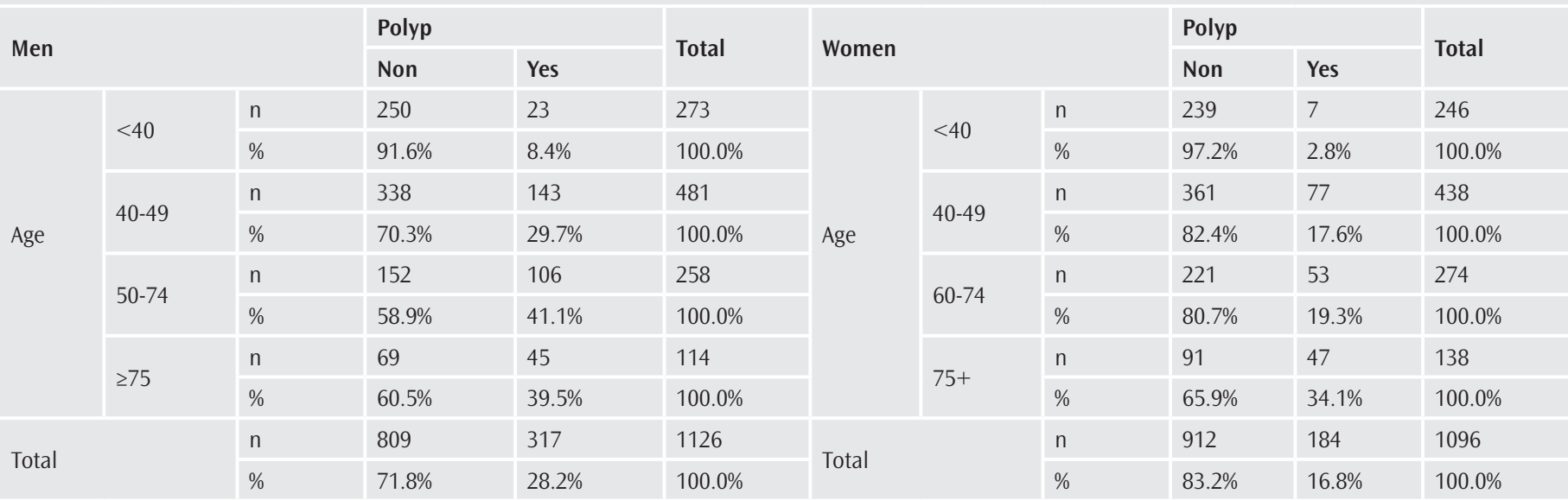

Table 2. Polyp diameters and numbers of polypectomies

\begin{tabular}{|c|c|c|c|c|c|c|c|c|}
\hline & & & \multicolumn{5}{|c|}{ Polyp size (mm) } & \multirow{2}{*}{ Total } \\
\hline & & & $<5$ & $6-10$ & $11-15$ & $16-20$ & $>20$ & \\
\hline \multirow{6}{*}{ Polypectomy } & \multirow{2}{*}{1 polyp } & $\mathrm{n}$ & 162 & 105 & 40 & 13 & 19 & 339 \\
\hline & & $\%$ & $47.8 \%$ & $31.0 \%$ & $11.8 \%$ & $3.8 \%$ & $5.6 \%$ & $100.0 \%$ \\
\hline & \multirow{2}{*}{2 polyps } & $\mathrm{n}$ & 90 & 70 & 23 & 6 & 5 & 194 \\
\hline & & $\%$ & $46.4 \%$ & $36.1 \%$ & $11.9 \%$ & $3.1 \%$ & $2.6 \%$ & $100.0 \%$ \\
\hline & \multirow{2}{*}{$\geq 3$ polyps } & $\mathrm{n}$ & 100 & 62 & 17 & 9 & 7 & 195 \\
\hline & & $\%$ & $51.3 \%$ & $31.8 \%$ & $8.7 \%$ & $4.6 \%$ & $3.6 \%$ & $100.0 \%$ \\
\hline \multirow{2}{*}{ Total } & & $n$ & 352 & 237 & 80 & 28 & 31 & 728 \\
\hline & & $\%$ & $48.4 \%$ & $32.6 \%$ & $11.0 \%$ & $3.8 \%$ & $4.3 \%$ & $100.0 \%$ \\
\hline
\end{tabular}

Table 3. Diminutive polyps in both genders

\begin{tabular}{|c|c|c|c|c|c|}
\hline & & & \multicolumn{2}{|c|}{ Diminutive polyp } & \multirow{2}{*}{ Total } \\
\hline & & & Non & Yes & \\
\hline \multirow{4}{*}{ Gender } & \multirow{2}{*}{ Men } & $n$ & 261 & 218 & 479 \\
\hline & & $\%$ & $54.5 \%$ & $45.5 \%$ & $100.0 \%$ \\
\hline & \multirow{2}{*}{ Women } & $n$ & 115 & 134 & 249 \\
\hline & & $\%$ & $46.2 \%$ & $53.8 \%$ & $100.0 \%$ \\
\hline \multirow{2}{*}{ Total } & & $n$ & 376 & 352 & 728 \\
\hline & & $\%$ & $51.6 \%$ & $48.4 \%$ & $100.0 \%$ \\
\hline
\end{tabular}

Table 4. Histopathological results

\begin{tabular}{|c|c|c|c|c|c|c|c|c|c|}
\hline & \multicolumn{8}{|l|}{ Histopathology } \\
\hline & & $\begin{array}{l}\text { Polyp diameter } \\
\text { inflammatory } \\
\text { polyps }\end{array}$ & $\begin{array}{l}\text { Tubular } \\
\text { adenoma } \\
\text { mild dysplasia }\end{array}$ & $\begin{array}{l}\text { Tubulovillous } \\
\text { adenoma } \\
\text { mild dysplasia }\end{array}$ & $\begin{array}{l}\text { Serrated } \\
\text { adenoma } \\
\text { mild dysplasia }\end{array}$ & $\begin{array}{l}\text { Tubular } \\
\text { adenoma } \\
\text { high dysplasia }\end{array}$ & $\begin{array}{l}\text { Hyperplastic } \\
\text { polyps }\end{array}$ & $\begin{array}{l}\text { Tubulovillous } \\
\text { adenoma } \\
\text { high dysplasia }\end{array}$ & Total \\
\hline \multirow{2}{*}{ Other polyps } & $n$ & 27 & 271 & 24 & 6 & 29 & 3 & 16 & 376 \\
\hline & $\%$ & $7.2 \%$ & $72.1 \%$ & $6.4 \%$ & $1.6 \%$ & $7.7 \%$ & $0.8 \%$ & $4.3 \%$ & $100.0 \%$ \\
\hline \multirow{2}{*}{$\begin{array}{l}\text { Diminutive } \\
\text { polyps }\end{array}$} & $n$ & 109 & 214 & 1 & 15 & 0 & 13 & 0 & 352 \\
\hline & $\%$ & $31.0 \%$ & $60.8 \%$ & $0.3 \%$ & $4.3 \%$ & $0 \%$ & $3.7 \%$ & $0 \%$ & $100.0 \%$ \\
\hline \multirow{2}{*}{ Total } & $n$ & 136 & 485 & 25 & 21 & 29 & 16 & 16 & 728 \\
\hline & $\%$ & $18.7 \%$ & $66.6 \%$ & $3.4 \%$ & $2.9 \%$ & $4.0 \%$ & $2.2 \%$ & $2.2 \%$ & $100.0 \%$ \\
\hline
\end{tabular}


examinations, and reduce complication rates. In an article published by the American College of Gastroenterology Association on the treatment of diminutive polyps, it was reported that most of the gastroenterologists (78\%) tend not to resect diminutive polyps in the middle- and highrisk groups of patients, the elderly, and patients under anticoagulant treatment (9).

A guideline developed by the American College of Gastroenterology Association provides the histopathological evaluation of diminutive polyps and the appropriate optical diagnosis. In this way, unnecessary polypectomies are avoided, complications are reduced, and great economic savings are achieved $(8,9)$.

One of the technologies enabling simultaneous histological diagnosis during colonoscopy is the high-resolution white light colonoscopy technique. The sensitivity rate is low and was reported to be $59 \%-84 \%$ $(10,11)$. Blue light used in narrow band resolution endoscopy, also known as virtual staining endoscopy or blue light endoscopy, reveals the mucosal details and vascular structures in adenomatous polyps, which are characterized by the excessive formation of new vessels and provides simultaneous histopathological information for diminutive polyps at an accuracy rate of 91\%-93\% during colonoscopy $(12,13)$.

Another important colonoscopy technique is the staining endoscopy. This technique was first used by the Japanese and recently gained popularity. When staining endoscopy is used with high-resolution endoscopy systems, concurrent histological diagnoses with an accuracy rate of $85 \%-96 \%$ have been reported $(14,15)$. This technique requires additional training and experience and slightly extends the colonoscopy time.

In their study, Lieberman et al. (3) detected polyps in 6,360 patients (45\%) in the screening colonoscopy of 13,992 asymptomatic patients. $28.5 \%$ of the patients had diminutive polyps. $1.7 \%$ of the diminutive polyps were found to have advanced precancerous histological characteristics (high-grade dysplasia, villous/tubulovillous, and serrated adenoma), while adenocancer was detected in only one case in a total of 3,744 patients (3). Because of this study, it was reported that there was no need to remove all of the diminutive polyps, and these patients could be followed up periodically.

In our study, polyps were detected in 501 (22.5\%) of 2,222 patients. The most frequent indications of colonoscopy were meteorism, constipation, abdominal pain, hematochezia, and anemia.

The polyp detection rate was significantly increased in men over 60 years of age and women over 75 years of age $(p<0.001)$. Polypectomy was performed for all polyps with a diameter greater than $5 \mathrm{~mm}$. However, patients with three or more diminutive polyps underwent excision of only three polyps. We recommended that all patients with polyps detected and excised should undergo a control colonoscopy within one year, following the American Gastroenterological Association postpolypectomy colonoscopy screening guideline (16). Three hundred fifty-two (48.4\%) patients had diminutive polyps. Regarding the gender, the rate of diminutive polyp detection was statistically higher in women $(p=0.003)$.
No adenocarcinoma was detected in the histopathological evaluation of the polypectomies. Sixteen (4.6\%) patients had an advanced-stage histopathology (tubulovillous and serrated adenoma). Although we have not detected adenocarcinoma in patients with diminutive polyps, the number of high-risk polyps was considerable.

Our result suggests that, at first glance, all polyps encountered in colonoscopy should be excised. However, when patient's characteristics, such as age, gender, and family history or risk factors for CRC, features of the colonoscopy device (high-resolution white light colonoscopy, narrow band resolution colonoscopy, etc.), and experience of the endoscopist are considered, we believe that patients harboring three or more diminutive polyps should be followed up at regular intervals.

The use of anticoagulant drugs and the presence of other comorbidities should also be considered among the patient-related factors. It should be kept in mind that each polypectomy increases both the duration of colonoscopy and the risk of complications.

To avoid unnecessary diminutive polypectomy procedures, it is important to use high-tech endoscopes together with staining endoscopies when possible. Alternatively, simultaneous histopathological evaluation of resected polyps in the colonoscopy unit is necessary. The capabilities of our country and the educational level of the patients and their access to colonoscopy should be considered if a follow-up protocol is to be made. Because of the importance of polypectomy in preventing the development of colon cancer, all polyps should be removed in patients who cannot come for colonoscopic control examinations.

\section{Conclusion}

In summary, in our series of 2,222 patients, advanced-stage histopathological results (19.9\%) were obtained in polyps larger than 5 $\mathrm{mm}$ in diameter. It is concluded that these polyps should be excised. Although the rate of advanced histopathological results in diminutive polyps was relatively low (4.6\%), we believe that some of the selected patients who did not undergo excision of all polyps should be included in the follow-up programs. Further multicenter studies with a larger case series are needed in this area.

Ethics Committee Approval: Ethical approval was obtained from İstanbul Esenyurt University (approval number: E-12483425-199-748).

Informed Consent: Written and oral consent were obtained from the patients included in the study, and their data were evaluated within the scope of the study.

Peer-review: Internally peer-reviewed.

Authorship Contributions: Surgical and Medical Practices - K.T., H.Ö.; Concept - K.T., H.Ö.; Design - K.T., H.Ö.; Data Collection or Processing K.T., H.Ö.; Analysis or Interpretation - K.T., H.Ö.; Literature Search - K.T., H.Ö.; Writing - K.T., H.Ö.

Conflict of Interest: No conflict of interest was declared by the authors.

Financial Disclosure: The authors declared that this study received no financial support. 


\section{References}

1. Kandel P, Wallace MB. Should We Resect and Discard Low Risk Diminutive Colon Polyps. Clin Endosc 2019; 52: 239-46.

2. Butterly LF, Chase MP, Pohl H, Fiarman GS. Prevalence of clinically important histology in small adenomas. Clin Gastroenterol Hepatol 2006; 4: 343-8.

3. Lieberman DA, Weiss DG, Harford WV, Ahnen DJ, Provenzale D, Sontag SJ, et al. Five-year colon surveillance after screening colonoscopy. Gastroenterology 2007; 133: 1077-85

4. Hassan C, Pickhardt PJ, Rex DK. A resect and discard strategy would improve cost-effectiveness of colorectal cancer screening. Clin Gastroenterol Hepatol 2010; 8: 865-9.

5. Lieberman D, Moravec M, Holub H, Michaels L, Eisen G. Polyp size and advanced histology in patients undergoing colonoscopy screening: implications for CT colonography. Gastroenterology 2008; 135: 1100-5.

6. Zauber AG, Winawer SJ, O'Brien MJ, Lansdorp-Vogelaar I, van Ballegooijen M, Hankey BF, et al. Colonoscopic polypectomy and long-term prevention of colorectal-cancer deaths. N Engl ] Med 2012; 366: 687-96.

7. Kessler WR, Imperiale TF, Klein RW, Wielage RC, Rex DK. A quantitative assessment of the risks and cost savings of forgoing histologic examination of diminutive polyps. Endoscopy 2011; 43: 683-91.

8. ASGE Technology Committee, Abu Dayyeh BK, Thosani N, Konda V, Wallace MB, Rex DK, et al. ASGE Technology Committee systematic review and metaanalysis assessing the ASGE PIVI thresholds for adopting real-time endoscopic assessment of the histology of diminutive colorectal polyps. Gastrointest Endosc 2015; 81: 502.e1-16.

9. Gellad ZF, Voils $\mathrm{Cl}$, Lin L, Provenzale D. Clinical practice variation in the management of diminutive colorectal polyps: results of a national survey of gastroenterologists. Am J Gastroenterol 2013; 108: 873-8.
10. Su MY, Hsu CM, Ho YP, Chen PC, Lin CJ, Chiu CT. Comparative study of conventional colonoscopy, chromoendoscopy, and narrow-band imaging systems in differential diagnosis of neoplastic and nonneoplastic colonic polyps. Am J Gastroenterol 2006; 101: 2711-6.

11. Ignjatovic A, East JE, Guenther T, Hoare J, Morris J, Ragunath K, et al. What is the most reliable imaging modality for small colonic polyp characterization? Study of white-light, autofluorescence, and narrow-band imaging. Endoscopy 2011; 43: 94-9.

12. Tischendorf JJ, Wasmuth HE, Koch A, Hecker $\mathrm{H}$, Trautwein $\mathrm{C}$, Winograd R. Value of magnifying chromoendoscopy and narrow band imaging (NBI) in classifying colorectal polyps: a prospective controlled study. Endoscopy 2007; 39: 1092-6.

13. Hewett DG, Kaltenbach T, Sano Y, Tanaka S, Saunders BP, Ponchon T, et al. Validation of a simple classification system for endoscopic diagnosis of small colorectal polyps using narrow-band imaging. Gastroenterology 2012; 143 : 599-607.e1.

14. Kudo S, Tamura S, Nakajima T, Yamano H, Kusaka H, Watanabe H. Diagnosis of colorectal tumorous lesions by magnifying endoscopy. Gastrointest Endosc 1996; 44: 8-14.

15. Chiu HM, Chang CY, Chen CC, Lee YC, Wu MS, Lin JT, et al. A prospective comparative study of narrow-band imaging, chromoendoscopy, and conventional colonoscopy in the diagnosis of colorectal neoplasia. Gut 2007; 56: 373-9.

16. Lieberman DA, Rex DK, Winawer SJ, Giardiello FM, Johnson DA, Levin TR Guidelines for colonoscopy surveillance after screening and polypectomy: a consensus update by the US Multi-Society Task Force on Colorectal Cancer. Gastroenterology 2012; 143: 844-57. 